\title{
Time Usage by College Students: Knowledge Acquisition, Degree Value, Work, Sleep and Fun
}

\author{
Alec Hanshaw \\ McMurry University \\ Paul M. Mason \\ McMurry University \\ Chung-Ping A. Loh \\ University of North Florida
}

Modern professors often lament at least the perception of declining amounts of time that today's college students allocate to knowledge acquisition relative to students from earlier eras. Employing a recently commissioned, 1,000+ response data set this paper investigates the hours allocated to learning and numerous other activities for students who attended college from the 1960s through those still in college, to investigate time usage over seven distinct time frames. The focus is on how time allocations have differed and potential justifications for those differences. The results reflect how time allocations have changed over the generations.

Keywords: Time Allocation, Knowledge Acquisition, Degree Acquisition, Cell Phones

\section{INTRODUCTION}

This paper concerns the time allocation decisions that current college students make compared to what earlier generations did when they were in college. Specific to effort in the classroom, do current students simply do the minimum that is necessary to get the degree (identified as degree acquisition); or rather, expend the necessary effort by allocating the time to acquiring knowledge (i.e., mostly skill development identified as knowledge acquisition) so as to leave college with expertise, abilities, and applicable insights to succeed in ones chosen profession and as a productive citizen? In parallel, did past college students consider these two components of their time allocation in the same way as today's college students?

Naturally, today's and yesterday's students have/had alternative uses of their time to balance against the hours allocated to getting value from their degree or simply getting the piece of paper (the two not being mutually exclusive). Some sleep is mandatory, as are food preparation and consumption; for many, outside work; and grooming and maintenance activities (e.g., leisure, transportation, shopping). Today's students seem to have more distractions like cell phones, U-tube, computers, social media, etc. with 
opportunity costs mandating reductions in other uses of time. However, past students faced longer times involved in things like cleaning, transportation, information acquisition, etc. that may have balanced things out with the modern distractions. This paper seeks to identify whether today's students and their recent predecessors allocate as much time (and presumably effort) to knowledge and degree acquisition compared to more seasoned former college graduates and non-graduates. Eight measures of time usage are incorporated in the analysis and there are seven time periods predicated on structural considerations including the Vietnam War, computers, cell phones, and Millennial and generation Z behaviors. The results based on detailed survey results from over one-thousand respondents are quite consistent with expectations that today's students are not allocating their time the same way their parents and grandparents did, and are not as much involved in knowledge acquisition either. This latter depressing outcome mandates some reconsideration of what our colleges and universities are providing to our young people today.

\section{COLLEGE HISTROY AND LITERATURE REVIEW}

Since 1940 the demand for college has increased dramatically. In that year, "Some College or Associates Degree" and "Bachelor's or Higher" comprised a total of 13\% of the American population. By 2009 , that rate increased to $60 \%$ (The College Board, 2019). The allocation of time in the 1940s was much different than today. World War II took up half of the decade, and once soldiers returned home the G.I. Bill sparked a higher education revolution. Before the 1940s most of the students enrolled in college were from upper middle and upper class families, but thanks to the G.I. Bill thousands of military veterans who would not have had the opportunity to attended college now could. By $1950 \mathrm{U}$. S. Gross Domestic Product (GDP) made up 27\% of the world's economy (Infogram, 2019), so wealth increases were larger and generated larger gaps than in previous decades. The American economy was reaching new heights each decade in the $20^{\text {th }}$ and $21^{\text {st }}$ century, and so too was undergraduate enrollment. In 1965 there were 5 million students enrolled in degree-granting postsecondary institutions, and by 2010 there were 20 million (National Center for Education Statistics, 2018).

There are relevant sub time periods within the last fifty years that have projected potentially different behaviors by college students relative to their time usage. The divisions are predicated on innovations and alterations within the economy that substantively affected college students and their use of time. These seven time modules are before 1968, 1968-1973, 1974-1980, 1981-2000, 2001-2007, 2008-2018, and since 2018.

When looking at the time usage of students who graduated before 1968, it is important to understand the climate for these enrollees. Most of these students were born in the 1940s and grew up during the start of the Cold War, and the early stages of America's dominance as a world superpower. College students who were male in this era likely served in the Korean War or found a way to avoid military service. The implements that were imperative for a college student were the typewriter, house phone, radio, record player, country roads, cars or trains for transportation, with checkable deposits at an all-time high as a medium of exchange. In the 1950s there were roughly 3 million students enrolled in higher education (U.S Department of Commerce, 1970).

"The 1950s and 1960s marked two major developments. First, large numbers of young people entered college and second, public colleges expanded dramatically to meet the demand. College enrollment rose by 49 percent in the 1950 s, partly because of the rise in the enrollment/population ratio from 15 percent to 24 percent. During the 1960s, enrollment rose by 120 percent" (U.S. Department of Education, 1993). Clearly the demand for college was expanding in America by the 1950s. America's economy was escalating rapidly so members of the middle class or veterans could afford the investment to attend college. With the passing of The Federal-Aid Highway Act of 1956, the efficiency in traveling across states was easier as well. This transferred demand for trains to the automotive industry. College students spent less time on country back roads or on trains in the late 1950s and early 1960s, so the students had more time for leisure and study. 
"The expansion of academic libraries in the 1950s was linked to the growth in revenues and enrollments in higher education. In 1950 there were a total of 1,851 academic institutions in the United States with an enrollment of 2,444,900; by 1959 there were 2,004 postsecondary institutions with an enrollment of 3,639,847 (Northam, 2014). There was also a boom in undergraduate libraries. Harvard University added a library in the late 1940s, specifically for their undergraduate students. The University of Michigan followed, adding an undergraduate library in 1958. In 1949, ACRL surveyed library construction projects and 24 libraries across the United States responded" (Northam, 2014). Northam discusses how the escalation of the Cold War incentivized the United States to invest in higher learning opportunities to compete with and surpass the rest of the world in education. The majority of time spent for a college student in this era would be in the classroom or library, since it would take more time to do homework. Typewriters, telephones, and radios were king in this era, and the time needed to prepare adequately for class would take relatively longer using the devices available then. An important shift to recognize in American culture during this era was when the public went from radios to televisions. The 1950s were a peak for radios in American households, but by 1960 around 90\% of Americans had a television present in their home (The Library of Congress).

The 1968-1973 era was an important graduation range because those years were the height of the Vietnam War, through the end of the war. "'College attendance to maintain a draft deferment most likely caused an increase in college enrollment rates among young men in the 1960's, and the elimination of the draft in the early 1970's probably had some negative impact on enrollment rates in succeeding years," (Bruno, 1984). The attendance rates of college enrollment also fluctuated before the Vietnam War, and after the Vietnam War. "The bureau reported that the college enrollment rate for civilian men 18 to 24 years old rose to 36 percent in 1969 from 24 percent in 1960 and then dropped to 27 percent in the mid1970 's, as the draft was dropped. The last draftee was inducted into the armed forces in June 1973" (Benefits Tied to Attendance, The New York Times, 1984). Time usage by college students in this era closely mirrored that of the previous group, but the highway system was more established, fast food became popular, air travel was becoming more affordable, televisions and cars improved, and the United States landed a man on the moon in 1969. Unlike prior decades, $55.4 \%$ of all male high school graduates would attend college in 1968 . This number fell to $46.6 \%$ in 1973 , and the $55.4 \%$ enrollment rate would not be surpassed until 1985 (National Center for Education Statistics, 1999).

The 1974-1980 time frame generated a large technological improvement in American life. College rates decreased slightly due to the draft not being mandatory, therefore not as many citizens could obtain G.I. benefits. College students in this time began to use the first digital camera which was invented in 1975, microwavable foods became dominant, fast food consumption grew dramatically and cassette players were increasingly popular. With these innovations in technology, college students had more leisure and study time, but still experienced several relative inefficiencies compared to today. The typewriter still dominated, telephones were the primary means of communication, but airlines were affordable relative to before and this increased the amount of people who could fly for the first time.

The 1981-2000 range represents the millennial group. It was estimated that 4 out of every 10 U.S. workers age 25 to 29 had a bachelor's degree, compared to the $32 \%$ of Generation X (Graf, 2017). Not only did this age group attend college at the highest rates compared to previous generations but there were numerous inventions that greatly served as tools for college students in this time period. In 1983 the internet was created. The Mackintosh was introduced to the public in 1984, and the Window's operating system launched in 1985. CD-ROM was created in 1985, the disposable camera in 1986, camcorders in 1983, the Cold War ended in 1991, and the cellphone was created in 1983 and widely used by the late 1990s. There was a technology revolution in America, and this greatly impacted the higher learning climate in the United States, and how students used their time. In 1980 there were 12,097,000 college students enrolled in the fall, and this number increased to 14,157,000 by 1991, and 15,300,000 in 2000 (National Center for Education Statistics, 2018).

The 2001-2007 time frame reflected the tech bubble in 2002 and the beginning of the financial crisis beginning at the end of 2007. College attendance rates continued to increase during this time, the cellphone was very popular, with 233,000,000 Americans using cell phones in 2006 (Infoplease, 2010). 
Computers became popular over typewriters in this era, DVD players also replaced VCR's, IPODs replaced Walkman's, cars got better gas mileage, and the internet was enhancing online entertainment and learning. This generation was born into the technology of the 1980s and 1990s, but when the mid to late 2000s hit, the technological advances were limitless. Students spent less time at the library than before because computers and laptops were replacing typewriters and books; and schools were also improving the efficiencies of their library systems. DVD's could store a monumental amount of information compared to VCR tapes, cassettes, records, and even books. This started the online learning movement, and it increased the amount of leisure time that college students had available.

By July 2007, the first iPhone launched. This device combined the telephone, iPod, computer, calculator, and many more innovations into a comfortable and efficient device that fits into ones pocket. In 2017 246,600,000 Americans had smartphones, and this number is supposed to reach 285,000,000 by 2023 (Statista, 2019). In the fall of 2016, the total college undergraduate enrollment was 16,900,000 students, a 20\% increase from 2000 (National Center for Education Statistics, 2018). With the numerous high-tech innovations and inventions introduced to the American public in this time frame, it was logical that college students were at the forefront of the adoption of these new technologies. In 2016, The Bureau of Labor Statistics did a study on the average breakdowns of how college students spend their time per day. On average in 2016 the average college student spent 8.8 hours sleeping, 4 hours on leisure and sports, 2.3 hours working or on related activities, 3.5 hours of educational activities, 1 hour eating and drinking, 0.8 hours grooming, 1.4 hours traveling, and 2.2 hours of other (The Bureau of Labor Statistics, 2016).

Ultimately, there has been a dramatic increase in college student demand over the decades, as well as invention and innovations in society. College students seem to be mavericks in all aspects of society, and the allocation of their time clearly reflects that reality. Perhaps college students have always been the same, just the world changes around them which allowed(s) them to take advantage of their resources. Whatever the case may be, clearly there is a high demand for college degrees in the modern workforce, the only question remains: "Is College Worth It?" Depending on how college students spend their time in college, this could impact the answer.

In fact, there is ongoing discussion within the popular and professional literature about the value versus the cost of a college education in the modern era. Accumulated U.S. student debt is now over $\$ 1.5$ trillion (Studentloanhero.com, 2019) while the early career earnings of many college graduates does not permit timely repayment, let alone much if any repayment by those who do not graduate (USA Today, 2015). There is also considerable literature that questions whether graduates really develop skills or abilities while in college that assist them as either employees or citizens (Arum and Roksa (not to be quoted without permission), 2011; Caplan, 2017, Krislov and Volk, 2014).

In his 2017 book entitled The Case Against Education: Why the Education System Is a Waste of Time and Money, Bryan Caplan, an economics professor at George Mason University postulates that on a relative basis, the knowledge gained from attending college only generates one fourth of the value that the mere act of acquiring the degree provides. Caplan argues that based on the very limited career earnings value of one, two, or three years of college without completing a degree, that the value of having the degree is what is paramount, not the skills or knowledge that attending college purports to provide. Like others before him (see for example Mason, et. al., 2011, which determines that the predominant factors that identify performance on the ETS field test in business are entering GPA, business GPA, and SAT/ACT scores), Caplan points to the realization that those students who enter college with greater skills, discipline, knowledge, and talent, leave the same relative way. In fact, he argues that a year in college "neither raises their productivity nor enriches their lives."

Critics of Caplan, including his George Mason University colleague and frequent lunch companion Steven Pearlstein, argue that Caplan understates the value of a college education by ignoring the peripheral advantages of college attendance like participation in or involvement with sports and other non-classroom experiences that "often reveal interests and hidden talents and help to shape character and ambition." In addition, long time college professors argue that proper instruction that focuses on skill development in students rather than simple memorization and regurgitation of facts promotes the 
importance of attending, and thus, promotes the intrinsic value. Caplan, as paraphrased by Pearlstein, implies that college reveals the ability "to put up with four years of (mostly) boring lectures and (mostly) tedious assignments in courses that (mostly) serve no purpose other than to test the perseverance and willingness to conform to a prevailing culture." Still others within the higher education industry point to the citizenry skill development that the acquisition of civics and other knowledge provides, along with the proficiency development that derives from human and non-human interactions both within and outside of the classroom.

Caplan also points to the results of assessment tests that reveal little or no retention of course material or dexterity development in critical thinking or statistical analysis. This is definitively disconcerting (particularly the latter). The question becomes, however, whether this result is the fault of the educational system, or the motivations and goals of the students. Pearlstein implies that you do not have to be an elitist to conclude that too many students are showing up at too many universities unprepared. That may be because high schools have failed to teach the knowledge or skills or study habits that they need, or that at 18 they are not emotionally mature enough for the challenge, or that they are simply bored by classroom learning. While much of the knowledge that is imparted in college classrooms is never to be seen again, the skills that are developed during the process are and should be transferrable to future life experiences and college can help develop these abilities - as long as the students do their part. However, the fundamental questions for this paper are what do students want from their educations, how do they budget their time to achieve these objectives, and how does the combination of the two influence the value they derive.

"What Good is a College Degree? Education and Leader Quality Reconsidered" (2015) by Nicholas Carnes from Duke University, and Noam Lupu from Wisconsin University analyzed cross-national data on random leadership transitions, data on close elections in the US Congress, and data on randomly audited municipalities in Brazil. Across a wide range of outcomes, they consistently found that collegeeducated leaders perform about the same as or worse than leaders with less formal education. Politicians with college degrees do not tend to govern over nations that are more prosperous, do not pass more bills, do not tend to do better at the polls, and are no less likely to be corrupt when compared to the counterparts with less education. These authors continue by contending that

"Scholars are beginning to reach the same conclusions about the links between educational attainment and performance in other skilled professions. Using longitudinal data on individual student achievement, Clotfelter et al. (2007) show that teachers who earn master's degrees do not produce greater learning gains for students (either before or after receiving their advanced degrees). Likewise, using data on the CEOs of companies traded on the New York Stock Exchange, Gottesman and Morey (2006) show that companies do not make greater profits when they are led by CEOs educated at more selective colleges or CEOs with law degrees or MBAs."

Their findings correlate with the central hypothesis here that a college degree does not always equal a better candidate, depending on the student's allocation of time. The advantages of going to college would be to engage in a classroom as an open and diverse environment. Freethinking, discussion, and debates take place on college campuses, which can prepare students to become natural leaders in their communities. Students are expected to learn from their mistakes in order to grow, and strive for lifelong learning.

When comparing the average salary of a high school diploma at $\$ 25,636$ a year, and the average salary of a Bachelor degree of $\$ 59,124$, there is no debate on why the attendance at colleges has hit record numbers (Josephson, 2018). The physical worth of a bachelor's degree is considerably more than a high school diploma. The wage gap is a big push or pull for many college students, but the worth is not derived from the physical acquisition of the degree, but rather, it is found in the journey to purse the degree. Being a college student means that one is persistent and overcomes hindrances. If a student can overcome obstacles in a learning environment, it should be clear they could when on the job. The quality of 
education has not worsened, but the approach students take to acquire a degree can point to effortminimization due to the average number of years to complete a four-year degree (5.1 years), or the high dropout rates.

Obtaining a college degree does not make one person better than the other, especially since not everyone can afford the average four-year cost of college, at $\$ 93,774$ (Studentloanhero.com, 2018). Higher education serves as a start of a life devoted towards learning, a process that continues once one graduates. Some scholars suggest that there is not a vast difference for people who do not have a college degree versus those who do when comparing leadership traits. Can this imply that a college degree has lost value?

"Of course not. It would be unreasonable to expect a college degree - or even an advanced degree - to signify anything beyond minimal proficiency in a profession as complex as government. Do we expect recent college graduates to perform brain surgeries? Do we expect students who have just passed the bar exam to design skyscrapers? Of course not-complex jobs require specialized training and heaps of supervised experience. It should come as no surprise that general educational attainment is not a marker of leader quality. It is not a marker of quality in many other complex jobs either" (same, authors and years).

There will always be certain specializations that will require higher learning. For medical doctors it is the MCAT and then eventually other medical boards, for lawyers it is the BAR. We expect engineers to be proficient in math, and teachers persistent enough to acquire a bachelor's degree, but then to continue to learn. College can make an individual a better leader, but that is not always the case. A leader is not always the smartest person in the room, but they have to have the ability to combine and orchestrate multiple talents in order to be productive. George Washington did not go to college, but times have changed. Then, the trend for higher education was rare, whereas today a majority pursue it. When there is competition to get a degree, a student has no choice not to get a bachelor's degree given certain expectations from employers.

Recently, the average student's effort relative to going to class was assessed by "USA Today College" (2018) implying that "[T] he average student misses $20 \%$ of the class vs. $80 \%$ of actually going to class. The average college student misses 240 classes over a four-year period, and $25 \%$ of all students miss a years' worth of college classes. Missing that many classes has an economic impact adding up to $\$ 7,200$ a year at public universities, and $\$ 24,960$ at private." This assessment ignores what they are doing during class (e.g., sleeping, texting, perusing Facebook, on Twitter, doing homework for other classes, or perhaps even paying attention and taking notes) However, if a student misses $20 \%$ of classes, then they would be losing roughly $20 \%$ of their degree value, beyond the piece of paper. It is hard to say if the value of a college degree has decreased, but if a student allocates proper time and effort, there is a greater likelihood that he/she will derive superior benefits beyond the piece of paper.

There are several papers similar to this one, including Fang 2013. That paper employs survey data to estimate that students work on average 19 hours per week, but she postulates that that number is rising subsequent to the Great Recession due to the rising costs of tuition and fees and the increasing shares that students and their families must to pay. Alternatively, Fosnacht, et. al. (2017) suggests based on NSSE surveys that the average freshman student works 6.3 hours per week for pay. It is likely that students tend to work more hours as they approach graduation but the disparity in the results of the two above papers is something this paper can analyze for the survey results herein. Clearly, however those students who do not have to or do not work can allocate more time to sleep, fun, etc., as well as their schoolwork and degree acquisition.

There are several recent papers, which have considered other usages of student time beyond going to and preparing for class and outside work. One of the biggest components is sleep. However, college students generally get less sleep than is recommended, and some of the alternative time might actually be relate to their studies. Kamenetz (2016) employs data for students who wore trackers to infer that 
students at 100 universities slept on average between seven and eight hours per night (seven hours three minutes on average during weeknights and seven hours and thirty-eight minutes on the weekend). Women went to bed on average at 1:00 am and guys just under forty minutes later. However, the author points out that $46.2 \%$ of the students slept less than seven hours per night. Campusmindworks from the University of Michigan (2016) points to the sleep deprivation of college students with a reference to the National Institutes of Health numbers that $73 \%$ of college students report some sleep problems, and that most get less than seven hours of sleep when eight hours is optimal. Another paper_reveals that the average college student gets less than seven hours of sleep per night and over $70 \%$ indicate that they feel sleep deprived (Gaille, 2017). A 2016 University of Georgia study puts the sleep number at between six and 6.9 hours per night (the University of Georgia, 2019).

Assessing the other standard categories of time use elsewhere in the literature can be accomplished by employing the American Time Use Survey, which was compiled into a relative assessment by Megan Oprea in a September 2016 article in thefederalist.com. She relates that beyond sleeping, students spend on average 3.4 hours per day on personal care (including eating and drinking, housework, grooming and shopping), 4.4 hours on leisure, 0.6 hours on family and community, and 1.8 hours on miscellaneous activities. One overlapping outcome cannot be ignored, however.

Outside of the personal care category, much of this non-educational, non-work component must contain cell phone use to understand current college students. There is extensive literature that debates the use of cell phones in the classroom (most implying that it is a major distraction), but the majority of the cell use is not educationally driven nor in class (despite the frustrations of college professors). A 2014 study by Roberts et. al., suggests that college women are on their cell phones on average ten hours per day and men nine! Clearly there must be joint production (if you can call it that) in personal activities and cell phone use because there are literally not enough hours in the week otherwise. However, for example, if college students are engaged in 70 hours per week on their cell phones, 65 hours per week outside of class; 20 hours per week working for pay (or none); 15 hours per week in class, and 49 hours per week sleeping, there are only 19 hours per week left for personal grooming, commuting, housework, community service, leisure, and oh, yes, preparing for class and studying. It is no wonder that college professors are so frustrated with students' time allocation and perceived unwillingness to study outside of class two hours for every hour in class as prescribed!

If one can assume outside work of 20 hours per week or nothing, that 135 hours per week is involved in other non-school activities (including 49 hours of sleep and 65 hours per week of other activities (based on cell phone use being joint with everything else), there are only 13 hours per week for class and outside preparation. Only those who do not work for pay can possibly have the time to do their schoolwork and attend class regularly! It is no wonder college students feel like they are too busy and stressed most of the time (until interestingly, they graduate and go to work fulltime and really understand constraints). This exercise also reveals a very important research reality: data taken from several sources is not likely to be comparable. The remainder of this paper looks at both the use of time by college students with an intergenerational focus, but also the time allocated to knowledge acquisition and degree acquisition. A discussion of the modelling is followed by results from the survey and conclusions.

\section{MODELS AND DATA}

The data for this study come from a commissioned survey of college graduates and those who did not graduate, conducted in October and December 2018. Four universities were contacted to assist in distributing the survey electronically to their current students and alumni. Currently, one of the universities is a private undergraduate institution, one is a private research university, the other two are public masters I institutions. It is important to note that at least one of the schools involved changed its type over the fifty years of this study so the respondent's assessment of what type of school it is/was when he/she attended is what is recorded. IRB processes were undertaken at the first institution and one of the master's schools, but the other master's school provided very little in the way of responses because of the unwillingness of the upper administration to help the dean of business to assist in the analysis and 
the other school required a faculty member there to be a sponsor and none arose. One of the authors of this paper had a connection with the latter school which allowed him to find an alternative way to access current students and (non)graduates at that school and that method was fruitful. Two hundred and fifty six usable responses from 312 submissions arose. Because the authors of this paper wanted a more robust sample, the Amazon Mechanical Turk process was employed to generate considerably more responses. The Mechanical Turk produced 1,307 responses but many of them generated nonsense answers like sleeping zero hours per week or attending class for 30 hours per week more than the classes met. Therefore, the Mechanical Turk data were culled to 794 useable responses generating a final data set of 1,050. The paper reports results for both the entire data set and the subset of the data other than from the Mechanical Turk process, due to the statistically significant implications of a dummy variable for the Turk data, but despite very few statistically significant differences in means by category. The three versions of the survey are available on request, the differences deriving because there were several different types of questions dependent on whether the respondents are still in school or not, whether they graduated or not, or whether they are/were working. Table 1 below provides the means and standard deviations from the significant questions on the surveys (those omitted will be explained in the results section).

\section{TABLE 1}

\section{MEANS AND STANDARD DEVIATIONS}

\begin{tabular}{|l|l|l|l|l|}
\hline Variable & Minimum & Maximum & Mean & Std. Dev. \\
\hline Graduation Year & 1964 & 2022 & 2009.81 & 12.2775 \\
\hline Type of University & 1 & 6 & 3.34762 & 2.05921 \\
\hline Age & 18 & 76 & 32.2095 & 11.5523 \\
\hline Marital Status & 1 & 3 & 1.91619 & 0.9636 \\
\hline Gender & 1 & 3 & 1.46952 & 0.50689 \\
\hline GPA & 1.25 & 3.75 & 3.38286 & 0.39445 \\
\hline Knowledge Acquisition & 0 & 82 & 19.3933 & 13.6678 \\
\hline Degree Acquisition & 0 & 84 & 10.7826 & 10.2713 \\
\hline Hours of class & 0 & 24 & 14.0989 & 4.91441 \\
\hline Hours attended & 0 & 25 & 12.5739 & 5.09496 \\
\hline Not paying attention & 0 & 60 & 11.449 & 12.0739 \\
\hline Studying outside & 0 & 60 & 12.7819 & 9.78591 \\
\hline Hours of work & 0 & 50 & 4.26333 & 8.13968 \\
\hline Minimum time & 0 & 168 & 14.3938 & 12.1515 \\
\hline Eating & 10 & 40 & 14.3224 & 6.75131 \\
\hline Grooming & 0 & 38 & 7.18295 & 4.50926 \\
\hline Leisure & 0 & 53.5 & 13.2776 & 9.48242 \\
\hline Sleeping & 20 & 76 & 47.8005 & 11.1812 \\
\hline Traveling & 0 & 50 & 4.80181 & 5.05141 \\
\hline Working & 0 & 80 & 19.8919 & 13.6065 \\
\hline Computer & 0 & 60 & 13.5148 & 10.0538 \\
\hline Cell phone & 0 & 55 & 8.48714 & 8.59576 \\
\hline Other & 0 & 55.5 & 10.367 \\
\hline
\end{tabular}


In the models, the reported amount of time spent in each activity category is specified as a linear function of gender, marital status, types of college/university attended, and the era in which the respondent graduated. For the latter, dummy variables were created indicating whether the graduation/matriculation fell in one of the following periods: 1968-73, 1974-80, 1981-2000, 2001-07, 2008-18, and after 2018 (still in school at the time of the data collection). The period before 1968 serves as the baseline. Specifically, the amount of time spent in activity categories $m(m=1, \ldots, M)$, denoted by $y_{m}$, is specified as

$y_{m}=X \beta_{m}+\delta_{m 1} D(1969 \sim 1973)+\delta_{m 2} D(1974 \sim 1980)+\delta_{m 3} D(1981 \sim 2000)$

$+\delta_{m 4} D(2001 \sim 2007)+\delta_{m 5} D(2008 \sim 2018)+\delta_{m 6} D\left(\right.$ after 2018) $+\varepsilon_{m}$

where $X$ is a vector of demographics, $D$ an indicator of the era in which the graduation year falls, and $\varepsilon_{m}$ the random error. The threshold years are chosen based on the discussion in the literature review section. Each coefficient $\delta_{m}$ represents the difference in time used in activity $m$ between the indicated period and the base period.

In order to identify the timing of significant change in time allocation, an alternative specification of the dummy variables was applied, which indicated whether the graduation/matriculation took place after specific year thresholds, including 1963 (the earliest data in the sample), 1967, 1973, 1980, 2000, 2007, and 2018. The amount of time spent in activity categories $m(m=1, \ldots, M)$, denoted by $y_{m}$, can be expressed as

$y_{m}=X \beta_{m}+\gamma_{m 1} D($ post 1967$)+\gamma_{m 2} D\left(\right.$ post 1973) $+\gamma_{m 3} D($ post 1980) +

$\gamma_{m 4} D\left(\right.$ post 2000) $+\gamma_{m 5} D\left(\right.$ post 2007) $+\gamma_{m 6} D\left(\right.$ post 2018) $+\varepsilon_{m}$

Each coefficient $\gamma_{m}$ represents the incremental effect of graduating after the respective threshold year on the time allocation. Note that $\beta_{m}$ and $\varepsilon_{m}$ in this alternative specification are mathematically equivalent to those in equation (1), while each $\delta_{m}$ reflects a linear combination of $\gamma_{m}$ s (e.g. $\delta_{m 2}=\gamma_{m 1}+\gamma_{m 2}$ ).

Regressions were estimated for multiple activity categories simultaneously using Zellner's seemingly unrelated regression, which accounts for correlation between the error terms $\varepsilon_{l}, \ldots, \varepsilon_{M}$. While the estimated coefficient will be identical to those from separate OLS estimation, efficiency gain is expected from the GLS estimators.

Supplementary analysis employed three more variables, including numbers of minutes distracted during classes, the amount of study time at work, and GPA. These specifications are separately estimated with a similar specification, however, these supplementary regressions are estimated using OLS with clustered standard error at the level of college major.

\section{RESULTS}

The primary statistical results of this analysis are reported in the lengthy Table 2, Table 3 which reports the dummy variables for time periods of graduation a different way and Table 4 which addresses the peripheral assessments. There were several questions that were asked which will likely be addressed in subsequent papers and so those results are not reported. In addition, the questions regarding time usage categories were asked twice to identify how respondents suggested they used their time without consideration of the 168 hours in a week, and then faced with that constraint. The latter results are the ones reported in Table 1 and employed herein.

In Table 2, each of the eight time usage components is reflected in a separate regression. Standard errors appear parenthetically under each coefficient. Not surprisingly, the overall significance of the regressions is weak given the cross-sectional nature of the data and the broad array of possible influences on time usage. However, there are robust implications relative to the intergenerational time allocations across the time usage categories. 


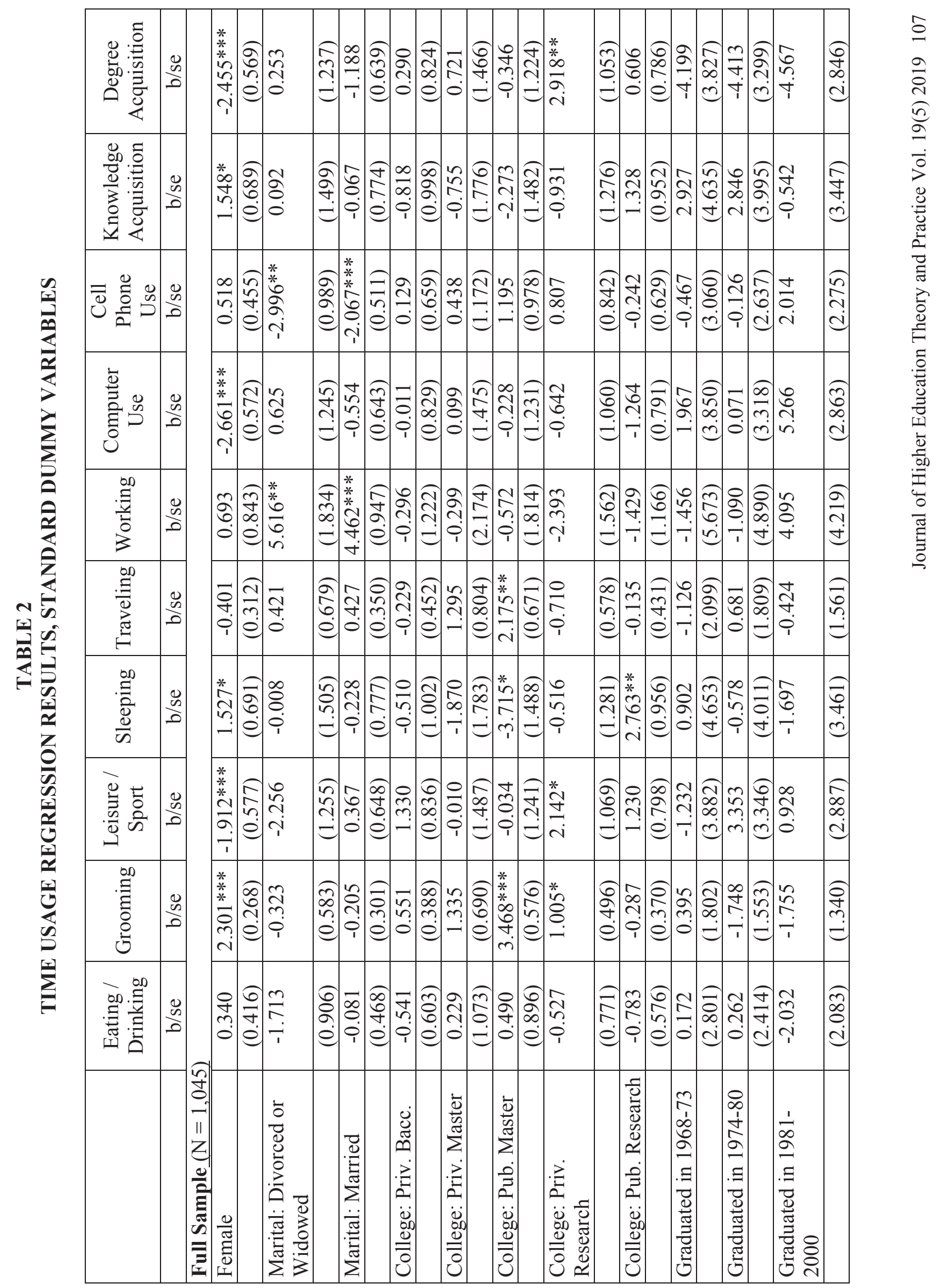




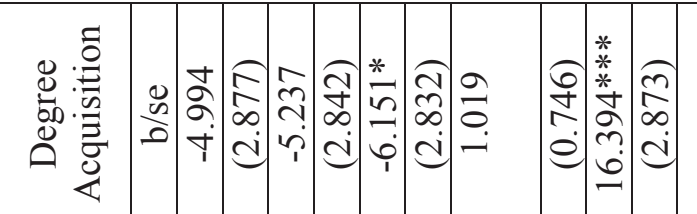

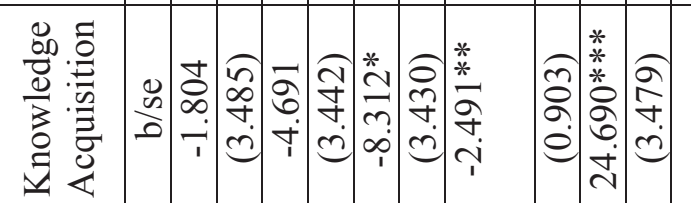

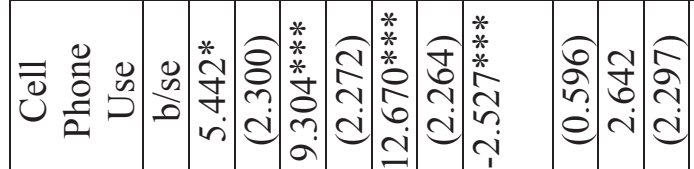

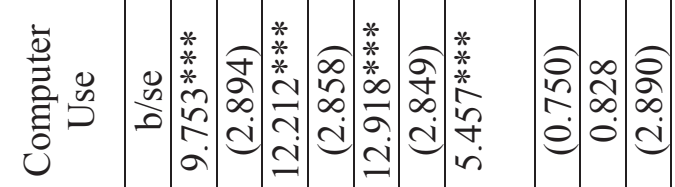

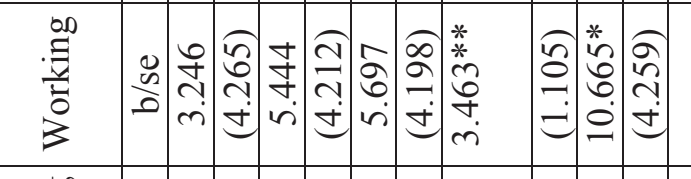

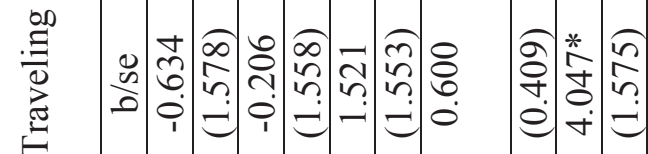

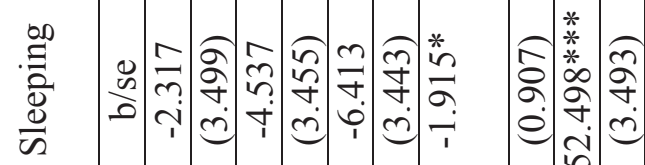

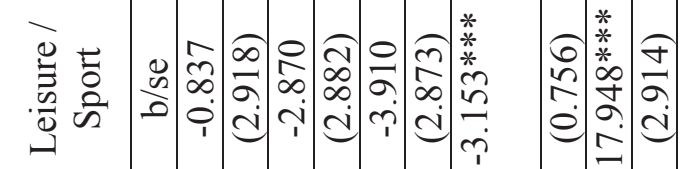

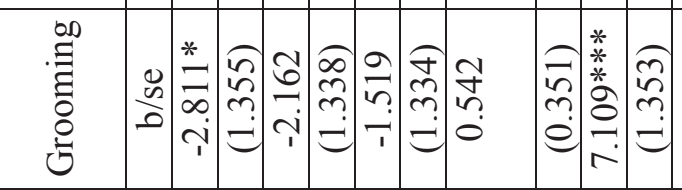

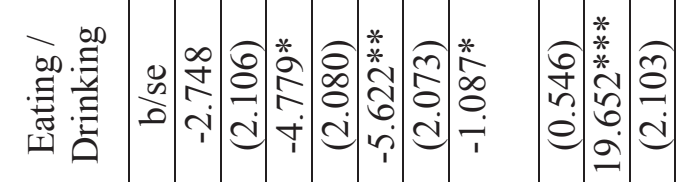

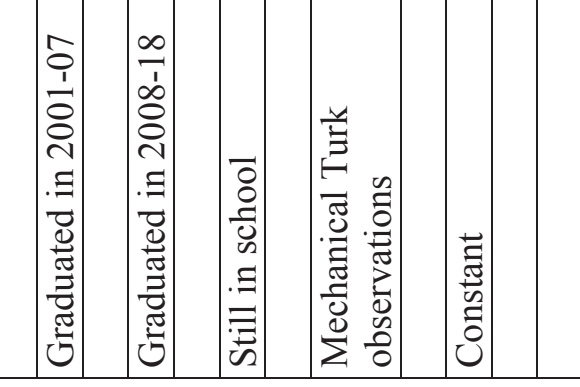

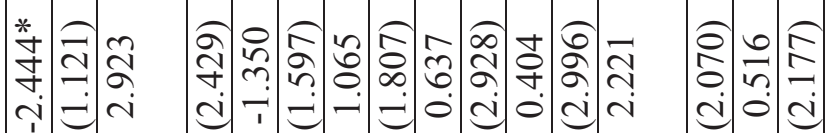

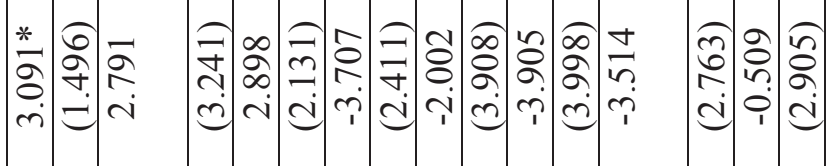

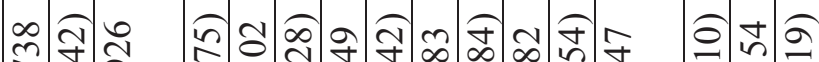

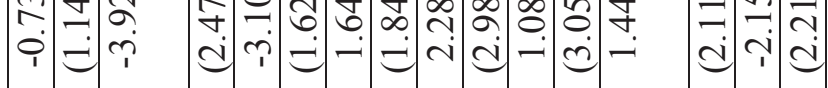

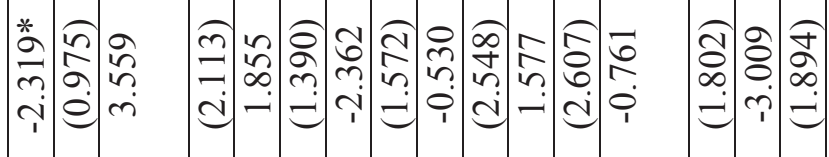

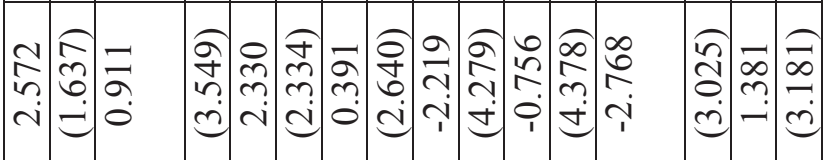

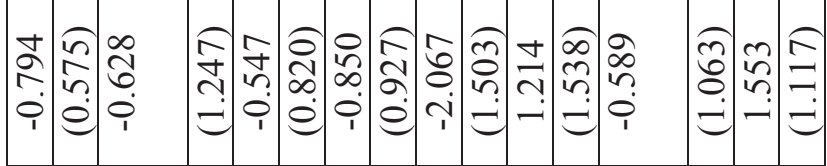

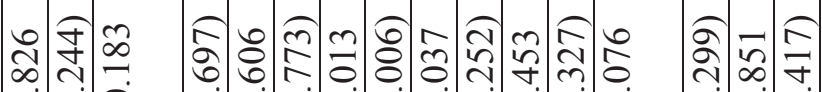

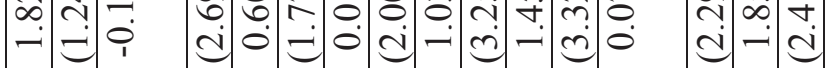

हो

* * *

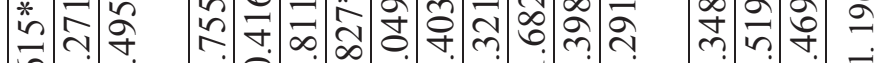

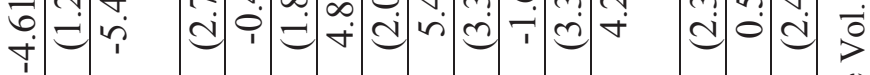

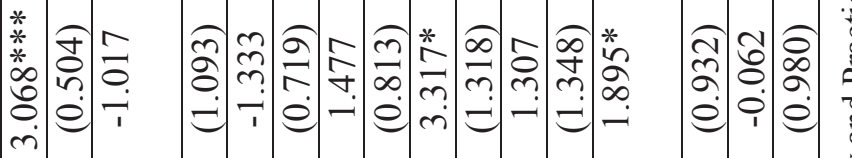

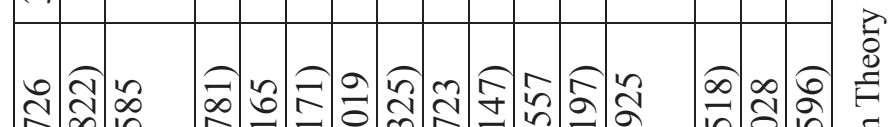

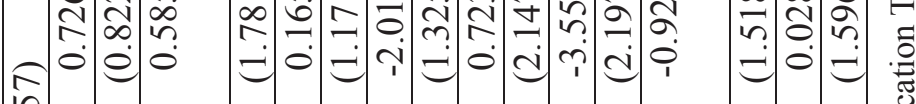

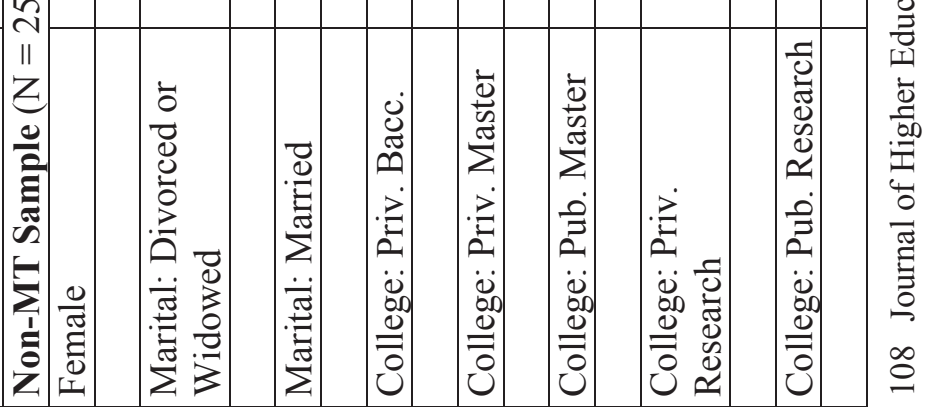




\begin{tabular}{|c|c|c|c|c|c|c|c|c|c|c|c|c|c|}
\hline 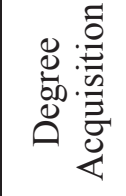 & $\begin{array}{l}0 \\
0 \\
0 \\
0\end{array}$ & $\mid \begin{array}{l}0 \\
m \\
n \\
i \\
1\end{array}$ & 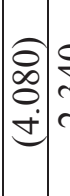 & 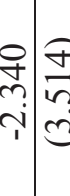 & 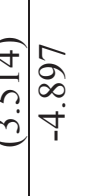 & $\begin{array}{c}0 \\
+ \\
0 \\
0 \\
0\end{array}$ & 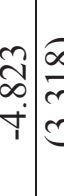 & 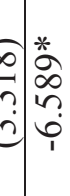 & 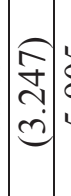 & 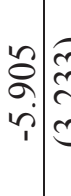 & 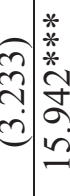 & 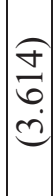 & \\
\hline 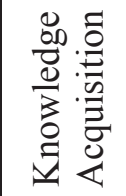 & $\begin{array}{l}\dot{D} \\
\infty \\
0\end{array}$ & $\mid$\begin{tabular}{c}
8 \\
\hdashline \\
$\dot{\theta}$
\end{tabular} & 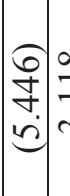 & 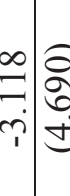 & 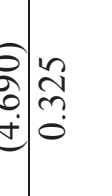 & $\begin{array}{l}\infty \\
2 \\
0 \\
\dot{ \pm} \\
\end{array}$ & 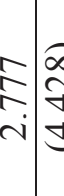 & 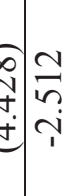 & $\begin{array}{l}\tilde{n} \\
\tilde{n} \\
\tilde{t} \\
\dot{U}\end{array}$ & 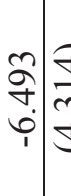 & 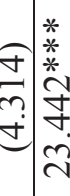 & 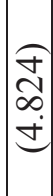 & \\
\hline 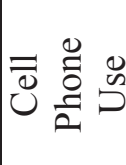 & $\begin{array}{l}\dot{v} \\
\text { in } \\
0\end{array}$ & 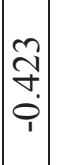 & 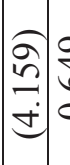 & 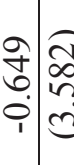 & 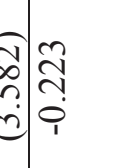 & $\begin{array}{l}2 \\
\dot{8} \\
\dot{0}\end{array}$ & 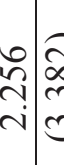 & 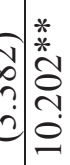 & 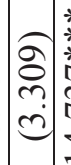 & 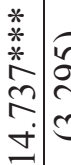 & 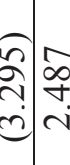 & 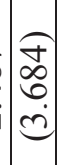 & \\
\hline 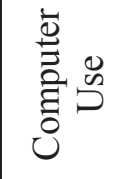 & $\begin{array}{l}\dot{v} \\
\frac{\omega}{2}\end{array}$ & $\mid \begin{array}{c}2 \\
\partial \\
\tilde{n} \\
\text { i }\end{array}$ & 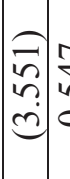 & 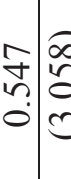 & 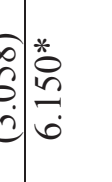 & $\begin{array}{l}6 \\
0 \\
0 \\
\text { co }\end{array}$ & 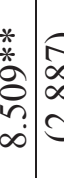 & 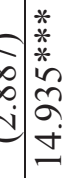 & $\begin{array}{l}\widetilde{2} \\
\mathfrak{i} \\
0 \\
\vdots \\
\mathfrak{d} \\
\vdots\end{array}$ & 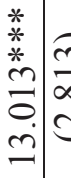 & 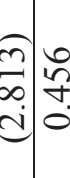 & $\frac{\widetilde{n}}{\square}$ & \\
\hline 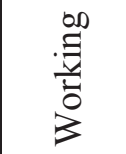 & $\begin{array}{l}\dot{D} \\
\vdots \\
0\end{array}$ & $\mid \begin{array}{l}\hat{\alpha} \\
\hat{\alpha} \\
1\end{array}$ & 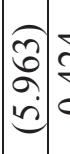 & 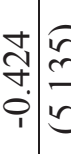 & 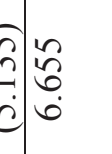 & \begin{tabular}{|}
$\tilde{f}$ \\
$\stackrel{f}{+}$ \\
$\dot{ \pm}$
\end{tabular} & 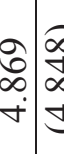 & 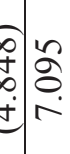 & $\underset{\stackrel{f}{+}}{\stackrel{f}{+}}$ & 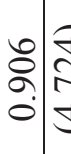 & 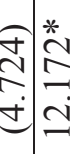 & 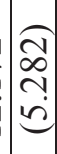 & \\
\hline 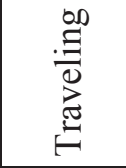 & $\begin{array}{l}\dot{0} \\
0 \\
0\end{array}$ & 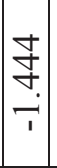 & 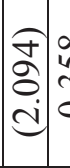 & 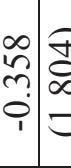 & 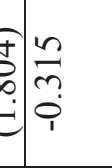 & 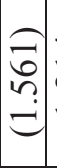 & 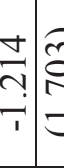 & 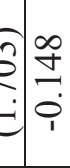 & 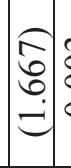 & \begin{tabular}{l|l}
$m$ & 0 \\
8 & 0 \\
0 \\
0 \\
1 & $=$
\end{tabular} & 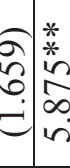 & $\begin{array}{l}\tilde{n} \\
2 \\
\infty \\
=\end{array}$ & \\
\hline $\begin{array}{l}\stackrel{\infty}{\Xi} \\
: \frac{0}{D} \\
\frac{0}{\infty}\end{array}$ & $\begin{array}{l}0 \\
\dot{m} \\
0\end{array}$ & $\begin{array}{c}0 \\
\tilde{\infty} \\
\infty \\
0\end{array}$ & 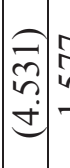 & 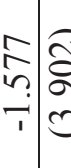 & 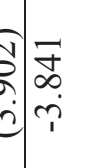 & $\begin{array}{l}6 \\
2 \\
m \\
0\end{array}$ & 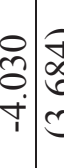 & 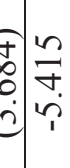 & 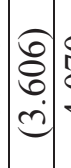 & 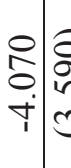 & 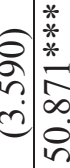 & $\begin{array}{l}\overparen{J} \\
\\
\dot{J}\end{array}$ & \\
\hline 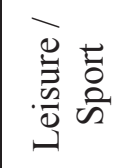 & $\begin{array}{l}0 \\
. \\
0 \\
0\end{array}$ & $\mid \begin{array}{l}0 \\
0 \\
0 \\
0 \\
0\end{array}$ & 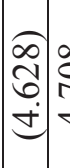 & 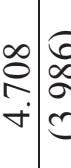 & $\begin{array}{c}0 \\
0 \\
0 \\
i \\
i\end{array}$ & $\mid \begin{array}{c}a \\
g \\
f \\
\dot{v}\end{array}$ & 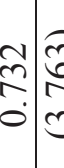 & 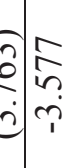 & $\begin{array}{c}\tilde{3} \\
0 \\
0 \\
\dot{0} \\
0\end{array}$ & 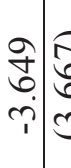 & 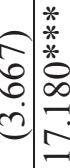 & $\begin{array}{l}\widehat{8} \\
8 \\
\dot{y}\end{array}$ & \\
\hline 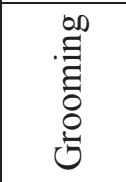 & $\begin{array}{l}0 \\
0 \\
0\end{array}$ & 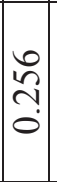 & 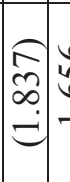 & 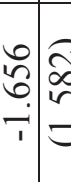 & 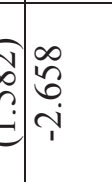 & {$\left[\begin{array}{c}0 \\
6 \\
- \\
= \\
=\end{array}\right]$} & 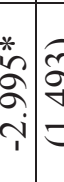 & ְُ & 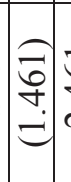 & \begin{tabular}{l|l}
5 & $\mid r$ \\
+ & 5 \\
$ن$ & 5 \\
1 & $=$
\end{tabular} & 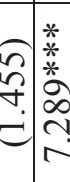 & 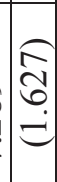 & \\
\hline \multirow[t]{2}{*}{ 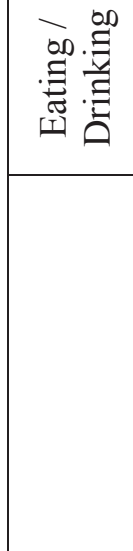 } & $\begin{array}{l}0 \\
0 \\
0 \\
0\end{array}$ & $\mid \begin{array}{c}\stackrel{\sim}{\mathcal{H}} \\
\stackrel{\sim}{\sim}\end{array}$ & $\mid \begin{array}{l}2 \\
\dot{a} \\
\dot{\alpha}\end{array}$ & 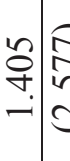 & 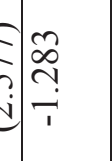 & 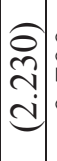 & 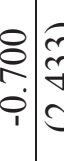 & 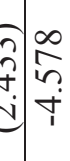 & 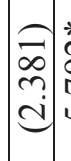 & 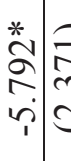 & 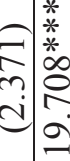 & $\begin{array}{l}\widetilde{\vec{n}} \\
\tilde{\sigma} \\
\dot{v}\end{array}$ & $\begin{array}{l}\overrightarrow{8} \\
0 \\
\dot{0} \\
\mathrm{v}\end{array}$ \\
\hline & & 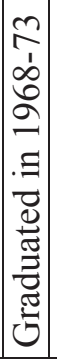 & & 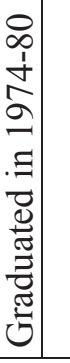 & 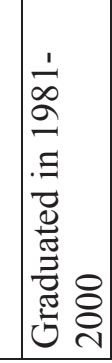 & & 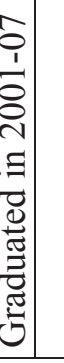 & 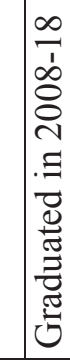 & & 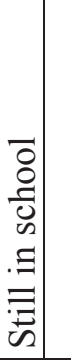 & 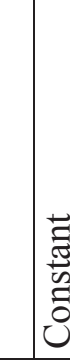 & & $\begin{array}{l}\dot{0} \\
\dot{\hat{V}} \\
2 \\
* \\
* \\
\tilde{0} \\
\dot{0} \\
\dot{v} \\
\text { * } \\
*\end{array}$ \\
\hline
\end{tabular}


The first consideration is time spent eating. None of the demographic nor college type variable coefficients are significant in either the non-Turk or total data set. However, in the total data set both the 2008-18 and still in school coefficients are significant at the 0.05 level or better and the still in school coefficient is also significant at the 0.05 level in the smaller non-Turk group. The magnitudes of these coefficients are revealing as well. Recent graduates spent almost 5 hours per week less eating than the control group (graduated before 1968, and by virtue of the insignificance of the other graduation time categories, those as well), while those currently in school spend 5.6 hours per week less eating than the other earlier graduates other than those graduating in 2008-18. The constant terms suggest around 19 hours per week of time eating for all with slightly less in the full sample than in the smaller non-Turk sample.

While one could argue that in many of the time use categories there have been efficiency gains in those activities, rate of eating has likely not been one of them. Therefore, the results likely reflect on the time constraints that current students face that their predecessors did not, or that recent graduates and current students had/have other activities that they preferred (e.g., cell phones and social media). This may be one place where today's recent graduates and current students find the time to play video games and use their smart phones.

The second time use category is grooming. Not surprisingly, females spent two or three hours more grooming than males in the full sample and non-Turk sample, respectively. In the full sample those who attended public masters level universities spent almost 3.5 hours more grooming than at the other university types (public baccalaureate schools being the omitted group), but those who graduated between 2001 and 2007 spent 2.8 hours less. Among the modern graduates, within the non-Turk sample those who graduated between 2008 and 2018 spent almost three hours less, but that did not carry over to the full sample. In both groups, grooming took up about one hour per day. Grooming is unlikely to be the source of changes relative to modern students.

The leisure and sports time use category reveals very little about intergenerational differences. Private research university students spent more time on leisure/sports by two hours in the full sample, and 4.8 more in the private baccalaureate category in the non-Turk sample. This latter outcome is likely the result of much of the data coming from one university in this category that has a large percentage of its student body in intercollegiate sports. There is literally no significant difference in the leisure/sports category across the generations. Today's college students may be playing video games and on their cell phones, but they do not identify these as leisure, or if they do, those activities have replaced other forms of leisure. The totals for leisure/sports are around 17-18 hours per week in both samples.

Sleeping also provides no intergenerational differences. Women slept/sleep about 1.5 hours more than men in the full sample, but not in the non-Turk sample. Public masters students slept/sleep 3.7 hours less but public research students spend 2.8 hours more in the sack. Overall, sleep is between 51 and 52.5 hours per week or the anticipated 7-8 hours per night found in other analyses. Contrary to speculation in other studies, sleep deprivation does not seem to be characteristic of those responding to our survey, nor does sleep seem to be a source for differentials in modern students relative to their predecessors.

Travelling is only different in our samples for public, masters universities (by just over 2 hours per week), but only in the full sample. Otherwise, travel has not changed, negating the commentary above about travel time efficiencies in the modern era. Those in our samples only travelled (non-commuting by definition in our directives for the survey) 4 to 6 hours per week so travel was a relatively small portion of the overall time allocation.

The only differentials relative to outside work were for those divorced or widowed (relative to the single people) and for those who are/were married while in college with the former 5.6 hours per week more and the latter 4.5 hours more. Once again, there were no intergenerational differences. The average work hours was consistent with the mean of prior research, between ten and twelve hours per week.

Getting to the more revealing outcomes, computer use was dramatically higher in those who graduated in the new millennium. For those in the 2001-2007 group, computer usage was 8.5 to 10 hours higher than the zero that likely existed in the pre-1968 period, which was insignificantly different from the other $20^{\text {th }}$ century graduates. Those in the most recent graduate category spent 12 to 15 hours more on 
the computer and those currently in school, consistently around 13 hours more than the control group. Although it may not be statistically significant, the slight drop for current students may reflect that they are using their phones instead of their computers. The reader should note that the survey directions requested computer usage for other than school work in this category. It is indicative of the dramatic, yet not unexpected change in this category that the constant terms in the two samples are both less than one, i.e., computer use is a $21^{\text {st }}$ century phenomenon for college students, virtually exclusively.

Cell phone use for non-school activities is similar to computers with some substantial differences. Married and divorced respondents used their cell phones respectively two and three hours less than single individuals, but once again, cell phone use only arose in the $21^{\text {st }}$ century (consistent with the reality that these devises almost did not exist before the year 2000). Cell phone use grew over the generations with over five hours per week in the 2001-2007 time frame, 9.3 hours for the 2008-18 graduates and 12.7 hours for current students. This is way below the evidence from Roberts, et. al., 2014 about nine and ten hours per day, but still sizable when one considers the bias towards not revealing how many hours one truly uses their cell phone. Ultimately, by insisting that the respondents fit their hours in totality in the 168 hour week they were faced with the reality of how many hours they truly have to be on their phones. This survey revealed no statistical difference between male and female students in cell phone use.

The remaining two time usage categories are the most important, knowledge acquisition and degree acquisition. The survey thoroughly explained the difference and that uses of cell phones and computers for university work was part of one or both of these. The two groups suggested that students on average spent between 23 and 24 hours per week on knowledge acquisition. This may sound sizable except the average time that students reported they were supposed to be in class was 14.1 hours. The number of hours students reported that they were actually in class was 12.6 so they were not present on average 1.5 hours per week or 24 hours in a semester. Although this estimate is considerably less than found in the paper cited above, it implies that the average student missed 24 one hour classes in a semester or roughly 2 class periods per course per semester. This is depressing enough except that when one looks at the experiences of more modern students it is worse.

The regressions reveal that while all groups before current students allocated the same number of hours to knowledge acquisition, those currently in college allocated 8.3 hours per week less to knowledge acquisition. Consequently they are allocating eight hours less to outside work for their classes, and the average evidence suggests only ten hours per week is/was being allocated at the mean, so current students are performing near zero hours per week to studying outside of class, or today's students are cutting even more classes than their predecessors, or some combination thereof. At least female students are allocating between 1.5 and 3 hours more than males so since women are dominating most college campuses the outcomes are not quite as bad. However, since the authors of this paper are all male, and one is currently a college junior, the data do not reflect favorably on particularly peers of the same gender as one of the authors.

The degree acquisition regression reveals that women are allocating about 2.5 hours less to degree acquisition beyond knowledge acquisition so they are likely getting more knowledge value from their degree relative to men as well. Otherwise, the only significant finding of this regression is that current students are allocating about six hours less to degree acquisition. Degree acquisition time is around 16 hours per week so about two-thirds of the time reported to be allocated to knowledge, so at least in aggregate, and even for current students, our respondents suggested that they were in college for the knowledge and not just to get the piece of paper. 


\section{When Did Some of the Significant Changes in Time Allocation Take Place?}

From the estimated results from specification (2) one can determine the shift in time allocation associated with each threshold year. As shown in Table 3, the threshold year 1980 is associated with a significant increase in time spent on the computer by 5.2 hours. An increase in one category should come with decreases in at least one of the other categories. The insignificant coefficients for this threshold year in other categories suggest that no one other category saw a systematic shift. The threshold year 2000 is associated with an additional increase in time use on the computer by 4.5 hours, and a significant rise in time spent on cell phones by 3.4 hours. Grooming time was reduced by slightly more than an hour. The threshold year of 2007, the year when the iPhone and the more matured smart phone technology hit the market, is associated with further increases in time use on computers by about 2.4 hours, and on cell phones by 3.9 hours. At the same time, time spent on knowledge acquisition systematically declined by 2.9 hours, while eating and drinking, leisure and sport, and sleeping also saw a significant drop in time allocation by 2 hours each. The threshold year 2018 is associated with a further increase in cell phone use by 3.4 hours, and a decline in time spent on knowledge acquisition by 3.6 hours. Sleep time has further declined by 1.9 hours, while traveling time rose by 1.7 hours. These results confirm those in Table 2 that modern students are substituting time on their computers and cell phones, NOT for school work or for knowledge acquisition.

In the non-Mechanical Turk sample, there are fewer significant changes but the results reflect the pattern in the full sample overall. The increases in time allocations to computer and cell phone use within threshold years appears more concentrated since 2007 . 


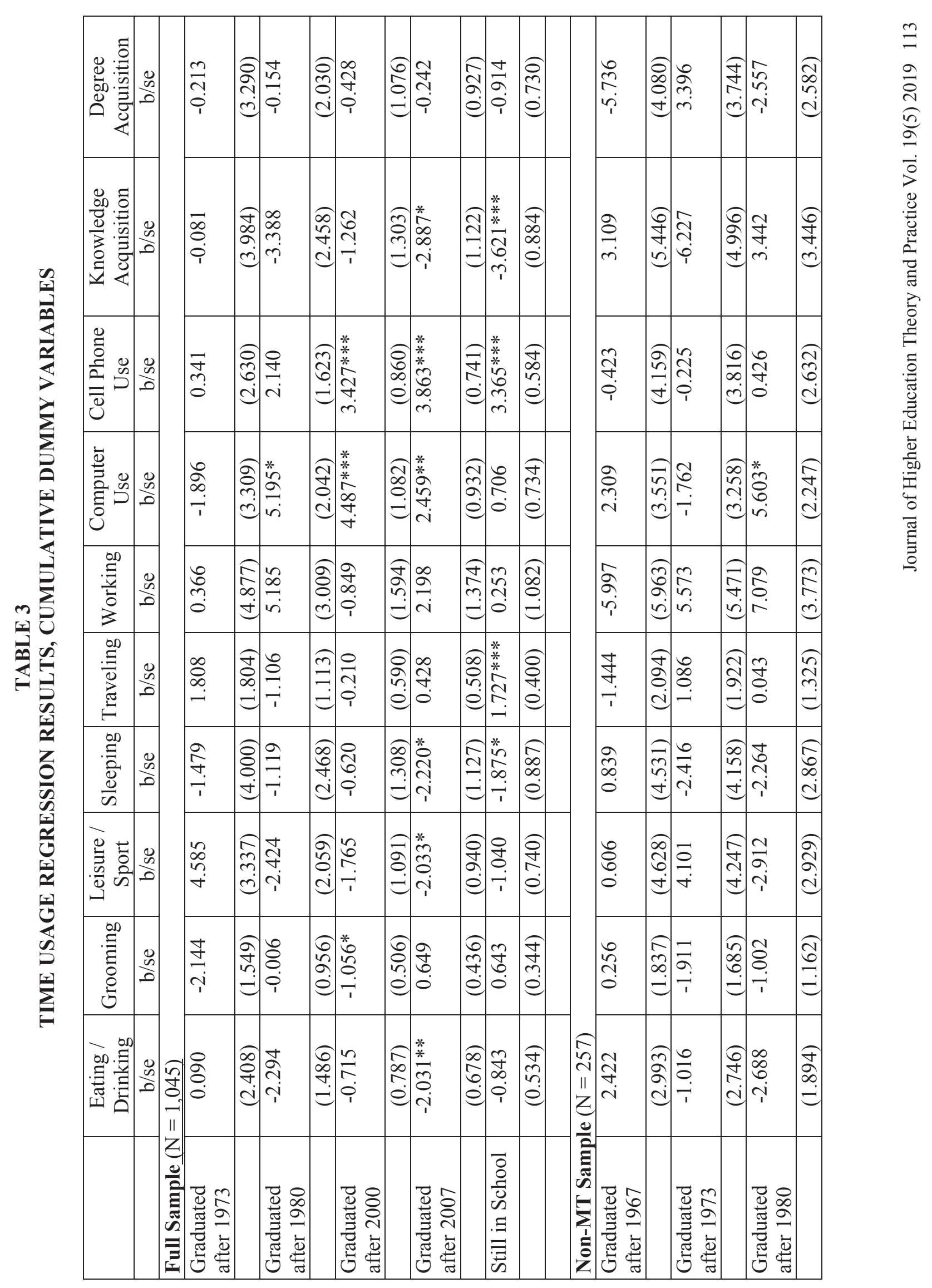




\begin{tabular}{|c|c|c|c|c|c|c|c|c|}
\hline 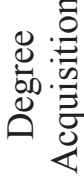 & $\mid$ & 吉 & તิ) & $\frac{3}{2}$ & 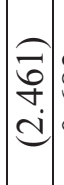 & $\begin{array}{l}\Re \\
\infty \\
0 \\
0 \\
0\end{array}$ & 合 & \\
\hline 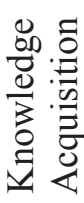 & 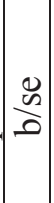 & $\begin{array}{l}\hat{n} \\
\stackrel{n}{\sim} \\
i\end{array}$ & \begin{tabular}{|c|}
2 \\
0 \\
0 \\
$\dot{0}$ \\
d.
\end{tabular} & $\begin{array}{l}\infty \\
\stackrel{\infty}{ } \\
\text { in } \\
r\end{array}$ & $\begin{array}{c}\widetilde{\sigma} \\
\infty \\
\sim \\
\\
\end{array}$ & $\begin{array}{l}\vec{\infty} \\
\hat{\sigma} \\
\vec{r} \\
1\end{array}$ & $\mid \begin{array}{c}\tilde{n} \\
\mathfrak{+} \\
\mathfrak{c} \\
\end{array}$ & \\
\hline 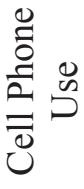 & $\mid$ & $\begin{array}{l}\stackrel{\gamma}{\curvearrowright} \\
\underset{\gamma}{\sim} \\
\sim\end{array}$ & $\begin{array}{c}\widehat{\widetilde{d}} \\
\tilde{n} \\
\mathfrak{d}\end{array}$ & 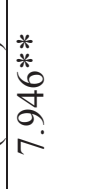 & 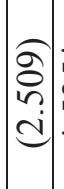 & 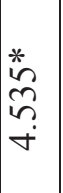 & 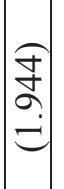 & \\
\hline 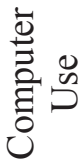 & \begin{tabular}{|l|}
0 \\
0 \\
0 \\
0
\end{tabular} & $\begin{array}{l}\stackrel{n}{n} \\
\sim \\
\sim \\
\sim\end{array}$ & ڤ̊. & 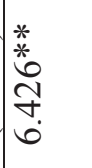 & 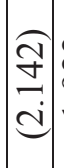 & 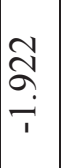 & 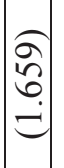 & \\
\hline 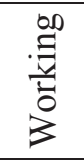 & $\mid \begin{array}{l}0 \\
0 \\
0 \\
0\end{array}$ & \begin{tabular}{l}
$\infty$ \\
$\infty$ \\
$\stackrel{1}{r}$ \\
\hdashline
\end{tabular} & 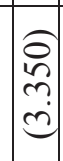 & $\begin{array}{l}\stackrel{\sim}{N} \\
\text { Na } \\
\text { vi }\end{array}$ & $\left|\begin{array}{c}\hat{\sigma} \\
\tilde{n} \\
\tilde{d}\end{array}\right|$ & 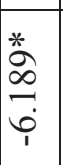 & $\begin{array}{l}0 \\
\infty \\
i \\
i \\
c\end{array}$ & \\
\hline 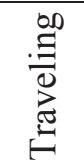 & $\begin{array}{l}0 \\
\dot{\infty} \\
0\end{array}$ & $\begin{array}{l}2 \\
\text { ळे } \\
0 \\
0\end{array}$ & 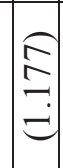 & 萬 & శ్ & $\frac{\mathscr{n}}{\stackrel{D}{ \pm}}$ & $\begin{array}{l}\widehat{\Omega} \\
\hat{\sigma} \\
\hat{e}\end{array}$ & \\
\hline 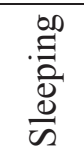 & $\begin{array}{l}\dot{v} \\
\frac{m}{2}\end{array}$ & $\mid \begin{array}{l}\infty \\
\infty \\
0 \\
1\end{array}$ & 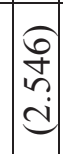 & \begin{tabular}{l}
$n$ \\
$\infty$ \\
$\cdots$ \\
\hdashline
\end{tabular} & $\begin{array}{c}\tilde{a} \\
\stackrel{2}{\tilde{d}} \\
\dot{d}\end{array}$ & 号 & 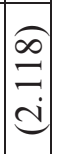 & \\
\hline 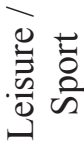 & $\begin{array}{l}0 \\
0 \\
0\end{array}$ & 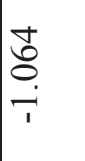 & $\begin{array}{l}\widehat{\vec{B}} \\
\mathbf{0} \\
\dot{d}\end{array}$ & 命 & 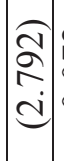 & $\begin{array}{l}\mathbb{N} \\
0 \\
\dot{0}\end{array}$ & $\begin{array}{c}\hat{\sigma} \\
\underset{\mathbf{c}}{\mathbf{c}}\end{array}$ & \\
\hline 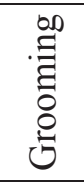 & $\begin{array}{l}\dot{D} \\
\frac{n}{2}\end{array}$ & $\begin{array}{l}\hat{n} \\
\text { n} \\
0\end{array}$ & 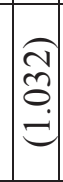 & \begin{tabular}{l}
0 \\
\multirow{2}{0}{} \\
0
\end{tabular} & 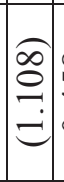 & \begin{tabular}{l}
$\infty$ \\
$\stackrel{n}{n}$ \\
\multirow{0}{0}{} \\
0
\end{tabular} & $\begin{array}{c}\infty \\
\infty \\
\infty \\
0 \\
0 \\
0 \\
\end{array}$ & 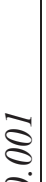 \\
\hline \multirow[t]{2}{*}{ 焉 } & $\frac{0}{0}$ & $\mid \begin{array}{l}+ \\
\infty \\
n \\
0\end{array}$ & 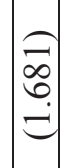 & $\begin{array}{l}* \\
\infty \\
\infty \\
\infty \\
\\
r\end{array}$ & $\mid \begin{array}{c}\tilde{\delta} \\
\infty \\
\doteq \\
\doteq\end{array}$ & $\frac{\Delta}{\stackrel{\Xi}{\top}}$ & $\begin{array}{l}\infty \\
\infty \\
2 \\
=\end{array}$ & $\begin{array}{c}v \\
* \\
* \\
* \\
* \\
0\end{array}$ \\
\hline & & 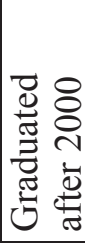 & & 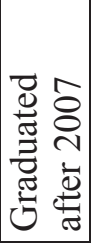 & & 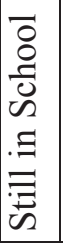 & & $\begin{array}{l}a \\
* \\
* \\
2 \\
\dot{0} \\
\dot{0} \\
V \\
2 \\
*\end{array}$ \\
\hline
\end{tabular}

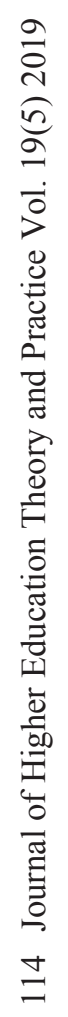


The peripheral implications of the analysis from the data in the paper appear in Table 4 reflective of the Table 3 methodology. The survey requested information on how many minutes out of 60 that students were not paying attention in class. The average for the total sample was just over 11, but the results suggest another 9.5 for today's college students. The latter implies 20.8 minutes out of sixty, or over onethird of the class period that today's students are not paying attention. Neither number is good or something college professors want to hear, but Pearlstein's commentary regarding boring lectures and Caplan's points about the value of college are reflected in the behaviors of students in class. One of the authors of this paper knows a student who would leave class to get a sandwich and then return without penalty. That student now has a Ph.D. If faculty are not providing value in class for students, they will vote with their attention and/or their presence.

The study time at work results are somewhat peculiar. The generation that graduated in the 1980 to 2000 period found almost five more hours per week to study at work while the first millennials who graduated college in the post 2000 period studied almost the same amount less at work. The post 2007 students went back to the same amount of work as those in the 1980s through 2000. Current students have not studied more or less at work than their immediate predecessors, however. It is not clear why these differences arose. However, other than those students at private master's universities studying about 3.25 hours less, there was nothing else that proved significant.

The last regression in Table 4 reflects on the intergenerational implications relative to GPA. Contrary to common assumptions regarding grade inflation across the decades, the results herein failed to reveal grade inflation or deflation at all. This may be because the survey requested GPA's within a limited number of ranges, but throughout the fifty-plus years in the time frame of the data, there was no significant display of trend in GPAs. The average GPA within the data was almost 3.2, with females having GPAs about 0.15 higher. Anybody within modern higher education should not be surprised by this latter finding, but probably readers are startled by the lack of grade inflation. There may be some bias associated with those still in college because their final GPAs have not yet been determined, but there is likely more bias from those not reporting lower GPAs, the non-graduates not being entirely truthful, or low GPA students not participating in the survey.

TABLE 4

SOME EXTRA IMPLICATIONS

\begin{tabular}{|l|c|c|c|}
\hline & Min Distracted & $\begin{array}{c}\text { Study Time at } \\
\text { Work }\end{array}$ & GPA \\
\hline Female & $\mathrm{b} / \mathrm{se}$ & $\mathrm{b} / \mathrm{se}$ & $\mathrm{b} / \mathrm{se}$ \\
\hline & -0.568 & 0.084 & $0.157^{* * *}$ \\
\hline Marital: Divorced or Widowed & $(1.860)$ & $(0.996)$ & $(0.043)$ \\
\hline & $-4.675^{*}$ & -1.095 & 0.077 \\
\hline Marital: Married & $(2.123)$ & $(0.884)$ & $(0.132)$ \\
\hline & -2.394 & 2.301 & 0.060 \\
\hline College: Priv. Bacc. & $(2.230)$ & $(1.384)$ & $(0.066)$ \\
\hline & -2.904 & -2.023 & -0.054 \\
\hline College: Priv. Master & $(2.972)$ & $(1.549)$ & $(0.079)$ \\
\hline & -2.548 & $-3.252^{*}$ & -0.009 \\
\hline College: Pub. Master & $(4.313)$ & $(1.465)$ & $(0.092)$ \\
\hline & -2.191 & 0.135 & -0.156 \\
\hline College: Priv. Research & $(4.085)$ & $(3.805)$ & $(0.142)$ \\
\hline & -2.960 & -1.601 & -0.150 \\
\hline College: Pub. Research & $(3.299)$ & $(2.098)$ & $(0.101)$ \\
\hline & -4.991 & -2.425 & -0.114 \\
\hline
\end{tabular}




\begin{tabular}{|l|c|c|c|}
\hline & Min Distracted & $\begin{array}{c}\text { Study Time at } \\
\text { Work }\end{array}$ & GPA \\
\hline Graduated after 1967 & -0.219 & 0.234 & -0.236 \\
\hline & $(2.499)$ & $(0.921)$ & $(0.224)$ \\
\hline Graduated after 1973 & -1.986 & 0.002 & 0.199 \\
\hline & $(2.195)$ & $(1.034)$ & $(0.218)$ \\
\hline Graduated after 1980 & 1.062 & $4.781 *$ & 0.137 \\
\hline & $(1.717)$ & $(1.854)$ & $(0.125)$ \\
\hline Graduated after 2000 & 2.780 & $-4.205 *$ & 0.050 \\
\hline & $(3.131)$ & $(1.770)$ & $(0.114)$ \\
\hline Graduated after 2007 & $9.665^{*}$ & $4.084 * *$ & -0.012 \\
\hline & $(4.336)$ & $(1.302)$ & $(0.140)$ \\
\hline Still in School & $-9.443 * *$ & -0.755 & -0.030 \\
\hline & $(2.892)$ & $(1.808)$ & $(0.076)$ \\
\hline Constant & $11.862^{* * *}$ & 0.514 & $3.187 * * *$ \\
\hline \multicolumn{2}{|l|}{$(3.444)$} & $(2.213)$ & $(0.146)$ \\
\hline R-squared & 0.087 & 0.021 & 0.026 \\
\hline $\mathrm{N}$ & 257 & 257 & 257 \\
\hline$* \mathrm{p}<0.05, * * \mathrm{p}<0.01, * * * \mathrm{p}<0.001$ & \multicolumn{3}{|l}{} \\
\hline
\end{tabular}

\section{CONCLUSIONS}

The evidence from a survey of 1,050 college graduates and non-graduates from four specific universities and from a mechanical Turk process suggest that student time usage has not changed much in most categories over fifty-plus years, but computer and cell phone usage outside of school has dramatically altered student time allocations since the year 2000, and particularly since 2008. Modern students allocating on average 20 to 25 hours per week to their computers and cell phones outside of use for school means those hours are not available for study or attending class. However, as speculated earlier in this paper knowledge acquisition time and degree acquisition time have fallen about 15 hours per week. While that is startling, it means that students are also reducing their time for sleeping, grooming, working, and especially eating, etc. too.

Students have seemingly always complained about being too busy. However, today's students and recent graduates in the last ten years have definitively had or have found new distractions that have increased the demands on their time. The efficiencies that were discussed early in this paper do not seemed to have dominated the changing conditions facing today's students. Rather, todays college students have technology to blame for why they feel squeezed for time, thus time management is even more crucial for them. Universities including the one where our student author matriculates have started to teach life management skills to their students. One of the ones that needs to be emphasized while the students are still in college is how to shut off the computers and the cell phones and study more. 


\section{REFERENCES}

A Look at the Shocking Student Loan Debt Statistics for 2019. (2109). Student Loan Hero. Retrieved February 3, 2019, from https://studentloanhero.com/student-loan-debt-statistics/.

Arum, R., \& Roksa, J. (2011). Measuring College Performance. Retrieved March 1, 2019, from https:/cepa.stanford.edu/sites/default/files/2011\%20Arum\%20\%26\%20Rokso\%201114_11.pdf

Bureau of Labor Statistics. (2016). Time use on average weekday for full-time university and college students. American Time Usage. Retrieved March 1, 2019, from https://www.bls.gov/tus/charts/students.htm

Caplan, B. (2018). What's College Good For? The World Might Be Better Off Without College for Everyone. Princeton University Press.

Carns, N., \& Lupu, N. (2019). What Good Is a College Degree? Education and Leader Quality Reconsidered. The Journal of Politics, 78(1). Retrieved September 23, 2015, from http://dx.doi.org/10.1086/683027. College Board. Trends in Higher Education.

Cell Phone Subscribers in the U.S., 1985-2010. (2018). Infoplease. Retrieved January 31, 2019, from https://www.infoplease.com/science-health/cellphone-use/cell-phone-subscribers us-19852010.

Clotfelter, C. T., Ladd, H. F., \& Vigdor, J. L. (2007). How and Why do Teacher Credentials Matter for Student Achievement? The National Bureau of Economic Research. Retrieved May 3, 2018, from https://www.nber.org/papers/w12828

College Board. (2019). Educational Attainment over Time, 1940-2009. Trends in Higher Education. Retrieved January 30, 2019, from https://trends.collegeboard.org/educationpays/figurestables/educational-attainment-over-time1940-2009.

College Enrollment Linked to Vietnam War. (1984). The New York Times. (1984). Retrieved January 31, 2019, from https://www.nytimes.com/1984/09/02/us/collegeenrollment-linked-tovietnamwar.html.

Digest of Education Statistics. Table 187, College enrollment rates of high school graduates, by sex: 1960 to 1998 [Numbers in thousands]. (1999). National Center for Education Statistics. Retrieved February 11, 2019, from https://nces.ed.gov/programs/digest/d99/d99t187.asp.

Dignan, S. (2016). The cost of skipping class, by the numbers. USA Today. Retrieved March 25, 2019, from https://www.usatoday.com/story/college/2016/02/26/the-cost-of-skipping class-by-thenumbers/37413317/

Fang, M. (2013). Think Progress. Nearly 80 Percent of Students Work While in School. Retrieved March 1, 2019, from https://thinkprogress.org/nearly-80-percent-of-students work-while-in-school2 f44edacd275/.

Fast Fact. Enrollment Trends. (2018). National Center for Education Statistics. Retrieved January 30, 2019, from, https://nces.ed.gov/fastfacts/display.asp?id=65.

Fosnacht, K., \& Calderone, S. M. (2017). Undergraduate Financial Stress, Financial Self Efficacy, and Major Choice: A Multi-Institutional Study. Journal of Financial Therapy, 8(1), 7. Retrieved February 22, 2019, from https://newprairiepress.org/jft/vol8/iss1/7/

Gaille, B. (2017). Small Business \& Market Advice. Sleep Deprivation Statistics in College Students. Retrieved May 3, 2018, from https://brandongaille.com/21sleep-deprivationstatistics-in-collegestudents/.

Gottesman, A. A., \& Morey, M. R. (2006). Does a Better Education Make for Better Managers? An Empirical Examination of CEO Educational Quality and Firm Performance. Retrieved May 21, 2018, from https://papers.ssrn.com/sol3/papers.cfm?abstract_id=564443

Graff, N. (2017). Today's young workers are more likely than ever to have a bachelor's degree. Pew Research Center. Retrieved January 30, 2019, from http://www.pewresearch.org/facttank/2017/05/16/todays-young-workers-are-more likely thanever-to-have-a-bachelorsdegree/. 
Hoist, A. (2019). Number of smartphone users in the United States from 2010 to2023 (in millions). Statista. Retrieved March 1, 2019, from https://www.statista.com/statistics/201182/forecast ofsmartphone-users-in-the-us/.

Josephson, A. (2018). Smart asset. The Average Salary by Education Level. Retrieved January 30, 2019, from https://smartasset.com/retirement/the-average-salary-by-education-level.

Kamentez, A. (2016). How College Students Are Sleeping ... Or Not. Retrieved May 3, 2018, from https://www.npr.org/sections/ed/2016/05/02/475581810/how-college_students-are-sleeping-or-not

Krislov, M., \& Volk, S. (2014). College Is Still for Creating Citizens. The Chronicle of Higher Education. Retrieved March 11, 2018, from https://www.chronicle.com/article/College-Is-Still-forCreating/145759

Making College More Expensive: Our View. Democrats' proposals do little to rein in costs. (2015). USA Today. Retrieved March 25, 2019, fromhttps://www.usatoday.com/story/opinion/2015/08/27/college-costs-plans-clintonsandersomalley-editorials-debates/31977025/

Moving Image Section--Motion Picture, Broadcasting and Recorded Sound Division. (n.d.). American Memory. Retrieved January 1, 2019, from https://memory.loc.gov/ammem/awhhtml/awmi10/television.html.

Northam, S. H. (2014). Cruising through the '50s: A decade in ACRL history. Association of College and Research Libraries, 75(10). Retrieved February 21, 2019, from https://crln.acrl.org/index.php/crlnews/article/view/9214/10216.

Oprea, M. G. (2016). Study: College Students Spend Far More Time Playing Than Studying. The Federalist. Retrieved January 3, 2019, from http://thefederalist.com/2016/09/11/study-collegestudents-spend-far-time-playing studying/

Pearlstein, S. (2018). Is college worth it? One professor says no. The Washington Post. Retrieved from August 2, 2018, from https://www.washingtonpost.com/business/why_higher-education-has-littleincentive-to-deliver-better-value/2018/03/08/a02684e0-224a11e8-94daebf9d112159c_story.html?noredirect $=$ on\&utm_term $=.2$ ccbe $4227 \mathrm{bd} 2$

Roberts, J. A., Manolis, C., \& Yaya, P. (2014). The invisible addiction: Cell-phone activities andaddiction among male and female college students [PDF File]. Journal of Behavioral Addictions, 3(4), 254-265. Retrieved April 3, 2018, from https://akademiai.com/doi/pdf/10.1556/JBA.3.2014.015

Share of world throughout history. (2019). Infogram. Retrieved January 31, 2019, from https://infogram.com/share-of-world-gdp-throughout-history-1gjk92e6yjwqm16.

SLEEP ROCKS! ...GET MORE OF IT! (n.d.). University Health Center, University of Georgia. Retrieved January 3, 2019, from https://www.uhs.uga.edu/sleep.

Tompor, S. (2015). College student's nightmare: Loan debt and no degree. USA Today. Retrieved February 3, 2019, from https:/www.usatoday.com/story/money/columnist/tompor/tompor/2015/06/07/studentloansrepay-delinquency-federal-reserve/28562447/.

120 Years of American Education: A Statistical Portrait [PDF File]. (1993). National Center for Education Statistics. Retrieved March 1, 2019, from https://nces.ed.gov/pubs93/93442.pdf. 